\title{
Behavioural response of juvenile bivalves to terrestrial sediment deposits: implications for post-disturbance recolonisation
}

\author{
V. J. Cummings*, S. F. Thrush \\ National Institute of Water and Atmospheric Research, PO Box 11-115, Hamilton, New Zealand
}

\begin{abstract}
In soft-sediment systems, terrestrial sediment deposits may result in a marked change in habitat and benthic community composition. We conducted a series of experiments to investigate the behavioural response of juveniles of 2 bivalve species common on New Zealand intertidal sandflats (Paphies australis and Macomona liliana) to terrestrial sediments. Both species are able to actively disperse as juveniles and do so in response to 'unfavourable' conditions. In the laboratory, we investigated the ability of these potential colonists to burrow into thin $(0.5,1.0 \mathrm{~cm})$ surface and submerged terrestrial sediment layers, and their subsequent ability to burrow into natural sediments. Field experiments assessed their response to terrestrial sediments that had been 'aged' in the natural estuarine environment for different lengths of time (up to $1 \mathrm{mo}$ ). Exposure to terrestrial sediment treatments negatively affected both species, with fewer individuals burrowing into the terrestrial sediment treatments. In the laboratory, burrowing was slower in the $1 \mathrm{~cm}$-thick surface layers than in the $0.5 \mathrm{~cm}$-thick and submerged layers, and the subsequent burrowing rate in natural sand of individuals recovered from these treatments was similarly affected. This latter effect is important as it suggests that settlement by juvenile bivalves on terrestrial sediment deposits can have a lasting effect even if an individual is able to find a more suitable habitat at a later date. In the field, dispersal of $M$. liliana away from the terrestrial sediment treatments was reduced, even after the sediment had been 'aged' on the sandflat. Depending upon the extent and frequency of disturbance, terrestrial sediments are likely to have important effects on the population and community dynamics of mobile bivalve species, and at a wider scale than that of their immediate impact.
\end{abstract}

KEY WORDS: Sedimentation $\cdot$ Recolonisation $\cdot$ Paphies australis $\cdot$ Macomona liliana $\cdot$ Post-settlement juveniles $\cdot$ New Zealand $\cdot$ Intertidal sandflats

\section{INTRODUCTION}

The persistence of a population over time or in a given geographical area often depends on its ability to disperse (e.g. Scheltema 1995). In soft-sediment systems, colonisation may occur via dispersal of a variety of life history stages (e.g. larvae, post-settlement juveniles and adults). Previously, larval dispersal was considered the major way that species colonised new areas, and for post-settlement individuals the general view was that crawling or burrowing was the predominant dispersal mode (e.g. Smith \& Brumsickle 1989).
However, this view has changed and post-settlement dispersal of adult and juvenile forms, particularly via the water column, is now well-documented (e.g. Butman 1987, Günther 1992, Armonies 1994, Cummings et al. 1995, Olivier et al. 1996a, Stocks 2002). While the relative contributions of the different modes of dispersal to the recovery of disturbed areas is not well known, post-settlement individuals are frequently important in recolonisation after disturbance (Baggerman 1953, Commito et al. 1995, Hunt \& Mullineaux 2002). It is generally considered that the larger the size of the disturbed area, the more important larval dis- 
persal is; however, given that many post-settlement organisms also disperse in the water column, these individuals are also likely to play an important role on a large spatial scale.

Sedimentation is a widely recognised disturbance agent in marine environments (e.g. Moore 1977, McFarland \& Peddicord 1980, Milliman \& Meade 1983, Peterson 1985, Smith \& Kukert 1996, Gray 1997, McClanahan \& Obura 1997, Alongi 1998, Edgar \& Barrett 2000, Cicin-Sain et al. 2002, Duarte 2002, Airoldi 2003), and the broad-scale degradation of valuable nearshore marine habitats due to elevated rates of sedimentation is of global concern (e.g. McKnight 1969, Peterson 1985, Lundin \& Linden 1993, GESAMP 1994, Gray 1997, Ellis et al. 2000). Sediment accumulation is often a result of discrete events that deposit terrestrial sediments during storms (e.g. Foster \& Carter 1997, Wheatcroft 2000), and a large proportion of the sediment deposited in the marine environment in such episodic events is derived from subsurface soils, associated with small landslides (Hicks et al. 2000). These terrestrial sediments have characteristics markedly different from those of marine sediments in terms of their nutrient content and geotechnical properties, and can be deposited on marine sediments of different particle size (e.g. Wheatcroft \& Borgeld 2000, Gibbs et al. 2001, Cummings et al. 2003, Hewitt et al. 2003).

Over time, terrestrial sediment deposits become incorporated into the ambient marine sediments, a process which can be facilitated by bioturbation of crabs and by erosion due to wind-wave action (e.g. Norkko et al. 2002, Cummings et al. 2003). Other deposits remain intact and move down the sediment column as the terrestrial deposit gets smothered by marine sediment. Finally, the deposit may become mixed with ambient sediments, and thus essentially 'diluted'. While the latter 2 mechanisms are more common for thinner allochthonous $(<5 \mathrm{~cm})$ deposits (e.g. Hewitt et al. 2003, Thrush et al. 2003), it is difficult to generalise, as environmental conditions play a major role in determining the fate of the deposits.

Field experiments designed to simulate stormassociated deposition of terrestrially-derived sediments on intertidal sandflats in New Zealand have documented the smothering of benthic communities by 2 to $10 \mathrm{~cm}$ deep deposits (Norkko et al. 2002, Cummings et al. 2003, Hewitt et al. 2003, Thrush et al. 2003). Furthermore, these experiments have shown that recovery is very slow (of the order of months to years). For example, numbers of macrofaunal colonists in $10 \mathrm{~cm}$ deep terrestrial sediment deposits remained lower than in natural sediments throughout a 4.5 mo experiment in Whangapoua Harbour (Cummings et al. 2003). The characteristics of these deposits remained considerably distinct from those of the surrounding sandflat (e.g. lower sediment chlorophyll $a$, higher clay, silt, $\mathrm{N}$ and $\mathrm{P}$ content than ambient sediments; Cummings et al. 2003), perhaps explaining why rapid recolonisation does not occur. In a companion experiment on the same sandflat, the macrofaunal community in $3 \mathrm{~cm}$-thick terrestrial sediments was still very unstable in comparison to the ambient macrobenthic community 20 mo after the deposition of the terrestrial sediment (Hewitt et al. 2003). The community composition of the terrestrial sediment plots varied from 1 sampling occasion to the next, and was comprised mostly of mobile taxa, with fewer individuals and taxa than the natural sandflat (Hewitt et al. 2003). This latter result was surprising, given that sand transported as bedload from the surrounding sandflat gradually covered the terrestrial deposits, and that large numbers of macrofaunal colonists (particularly bivalves) are generally transported with bedload (e.g. Emerson \& Grant 1991, Commito et al. 1995, Hewitt et al. 1997). Thus it appears that bivalves dispersing as juveniles do not settle and become established in these deposits.

This paper describes the results of a series of laboratory and field experiments designed to investigate the behavioural response of juveniles of 2 bivalve species (i.e. the mesodesmatid Paphies australis and the tellinid Macomona liliana) to terrestrial sediment deposits. Both species are common and ecologically important in benthic communities on sandflats throughout New Zealand. They are able to actively disperse as juveniles, in association with bedload transport and by drifting in the water column (Cummings et al. 1993, 1995, Hooker 1995, Hooker \& Creese 1995, Norkko et al. 2001), and are known to do so in response to 'unfavourable' conditions (e.g. the presence of tube-building spionid polychaetes, toxins; Pridmore et al. 1991, Cummings et al. 1996). We investigated the effect of exposure to terrestrial sediments on the burrowing ability of these bivalves in static laboratory conditions, and used field experiments to assess their response to terrestrial sediments that had been exposed to the natural estuarine environment for different lengths of time. Our study investigated responses to thin $(1.0$ and $0.5 \mathrm{~cm}$ ) layers of terrestrial sediment; such deposits occur frequently throughout New Zealand and the Pacific Rim (Lohrer et al. 2004). As our laboratory experiments were conducted in static water, the only responses possible for an individual were to burrow into the terrestrial sediment, or remain on the surface: they were unable to crawl or drift away. Thus, the aim of the field experiments was to determine whether juvenile $P$. australis and/or $M$. liliana exhibit a behavioural response to terrestrial sediment deposits when they are exposed to natural flow conditions. We hypothesised that: (1) juvenile 
bivalves would burrow more slowly in terrestrial deposits than in natural sediments; (2) exposure to the terrestrial sediments would affect the juveniles ability to subsequently burrow in natural sediments; and (3) in the natural field situation, the rate of dispersal of juveniles' from experimental terrestrial sediment deposits would be higher than from natural sediments.

\section{MATERIALS AND METHODS}

Species descriptions and collection methods. The bivalves Paphies australis and Macomona liliana are common on intertidal sandflats in estuaries throughout New Zealand. The deposit-feeding $M$. liliana inhabit sandy sediments at around mid-low tide level, while the suspension-feeding $P$. australis occur lower on the shore, in more exposed areas with high flow velocities and relatively coarse sediments.

Juvenile Paphies australis and Macomona liliana were collected by sieving surface sandflat sediments (top 1 to $2 \mathrm{~cm}$ ) in seawater. P. australis were collected using a $2 \mathrm{~mm}$ mesh, while $M$. liliana were sieved on a $500 \mu \mathrm{m}$ mesh. The sieve sizes used varied for each species due to differences in the sediment grain size of their respective habitats. Although the $P$. australis used in these experiments were larger than the M. liliana, it is likely that they were of similar age (i.e. $\leq 1 \mathrm{yr}$ old) as $P$. australis reach a considerably larger size as adults. Details of the collection sites are given below.

Terrestrial sediments. The terrestrial sediments used in the laboratory and field experiments were collected from 1 of 2 different catchments on the east coast of the northern North Island (i.e. Whangapoua on the Coromandel Peninsula, and Whitford in the Auckland region). In both catchments, the terrestrial sediments have a higher mud content (i.e. silt and clay) than their respective sandflat sediments. The 2 catchments differ in the proportion of silt their sediments contain. The Whangapoua sediments are subsurfacelayer volcanic clays dominated by kaolin minerals. The terrestrial sediments obtained from this catchment comprised $2.8 \%$ clay, $38.5 \%$ silt, $56 \%$ fine sand and $2.7 \%$ medium sand. The Whitford sediments are New Zealand brown soils, dominated by kaolin and vermiculite. These terrestrial sediments comprised $6.46 \%$ clay, $72.82 \%$ silt, $18.3 \%$ fine sand, $1.24 \%$ medium sand and $1.18 \%$ coarse sand. All sediments were mixed with seawater (either 60:40 or 70:30 seawater:sediment) prior to being used in the experiments. Previous experiments had shown that the amount of seawater with which the sediments are mixed prior to deposition on the sandflat has no detectable effect on macrofaunal recolonisation (Cummings et al. 2003).
Laboratory experiments. A series of laboratory experiments were conducted to assess the ability of Paphies australis and Macomona liliana to burrow into terrestrial sediment deposits (see Table 1 for summary and details of experiments conducted). Experimental treatments were chosen to investigate the effect of the thickness of surface layers (i.e. $1 \mathrm{~cm}$ vs $0.5 \mathrm{~cm}$ ), as well as the presence of a subsurface layer (i.e. a $0.5 \mathrm{~cm}$ terrestrial sediment layer covered by $0.5 \mathrm{~cm}$ of ambient sediment). The latter treatment was included to mimic our field observations, which show that terrestrial sediment deposits may gradually become buried by sediments from the surrounding sandflat transported with bedload (Hewitt et al. 2003, Thrush et al. 2003). All experiments also included a 'control' sand treatment. This consisted of ambient sediment collected from the same sandflat as the bivalves that had been sieved to remove fauna $(2 \mathrm{~mm}$ and $500 \mu \mathrm{m}$ mesh for $M$. liliana and $P$. australis experiments, respectively), frozen overnight to defaunate and then thawed and washed thoroughly with seawater.

Experiments were conducted separately for each species in static aerated seawater at 20 to $21^{\circ} \mathrm{C}$, under approximately $12 \mathrm{~h}: 12 \mathrm{~h}$ light:dark conditions. Paphies australis were collected from a sandflat in Whitianga Harbour, Coromandel Peninsula, and ranged from 6.0 to $16.0 \mathrm{~mm}$ in shell length. Macomona liliana were collected from the Wairoa Island sandflat, Auckland, and ranged from 1.5 to $3.6 \mathrm{~mm}$ in shell length. Bivalves were collected from sandflats adjacent to field experimental sites (described in next subsection) and were used in experiments within $24 \mathrm{~h}$ of collection.

Each treatment replicate was established in a small plastic cup (5 cm diameter, $4.5 \mathrm{~cm}$ high). A $2 \mathrm{~cm}$-deep layer of control sand was added to each cup, and the appropriate terrestrial sediment treatment was added on top of it. Replicates of each treatment were arranged in a randomised block design in $10 \mathrm{~cm}$-deep trays. The trays were filled to within $1 \mathrm{~cm}$ of the top with aerated seawater; thus $6 \mathrm{~cm}$ of water covered the surface of the $1 \mathrm{~cm}$ surface and the submerged terrestrial sediment treatments, and $6.5 \mathrm{~cm}$ deep water covered the $0.5 \mathrm{~cm}$ surface terrestrial sediment treatment. The appropriate numbers of individual bivalves were then added to each replicate: i.e. 5 Paphies australis or 10 Macomona liliana (see Table 1). The number of individuals that had not burrowed was noted over several hours following addition (see Table 1 for observation details). This phase of the experiment will be referred to as 'initial burrowing'. After the final observation, all individuals were recovered from each treatment replicate by gently sieving the sediments in seawater. To determine whether exposure to the treatments had affected their ability to reburrow in control sand, all bivalves were then added to cups containing a $2 \mathrm{~cm}$ layer of control 
sand, while still keeping replicates of each treatment separate. The number of individuals that had not burrowed was then noted over the following several hours, as described for the treatment sediments (Table 1). This phase of the experiment will be referred to as 'reburrowing'. The number of individuals is expressed as a percentage of those added to each replicate (mean $\pm \mathrm{SE}$ ).

Field experiments. Site descriptions: Field experiments with Paphies australis and Macomona liliana were conducted on different sandflats, with a high ambient density of each species. Bivalves were collected from these sandflats by sieving surface sediments, as described for the laboratory experiments.

Paphies australis field experiments were conducted at mid low-tide level on an intertidal sandflat in Whitianga Harbour ( $\left.36^{\circ} 50^{\prime} \mathrm{S}, 176^{\circ} 11^{\prime} \mathrm{E}\right)$, Coromandel Peninsula. These sandflat sediments are comprised predominantly of medium $(45 \%)$, fine $(25 \%)$ and coarse $(24 \%)$ sand. Densities of juvenile P. australis ranged from approximately 2 to 20 individuals $0.0177 \mathrm{~m}^{-2}$.

Macomona liliana field experiments were conducted at mid-tide level on an intertidal sandflat in the Whitford Embayment ( $36^{\circ} 54^{\prime} \mathrm{S}, 174^{\circ} 57^{\prime}$ E), near Auckland. Sediments at this site are comprised mostly of fine sand $(98.2 \%)$. Densities of juvenile M. liliana at this site ranged from approximately 1 to 12 individuals $0.0177 \mathrm{~m}^{-2}$.

Terrestrial sediment preparation: To investigate whether colonisation of terrestrial sediment deposits by bivalves was affected by the length of time the terrestrial sediment remained in the estuarine environment, a 'source plot' of terrestrial sediment was established on each sandflat. Terrestrial sediment was collected from a nearby road-cutting/landfill and mixed with seawater in a concrete mixer. It was then sprayed into a 2 m-diameter area on the sandflat to a depth of $5 \mathrm{~cm}$. The source plot was surrounded by a metal ring, which had been previously inserted into the sediment so that about $10 \mathrm{~cm}$ protruded, thus preventing the terrestrial sediment from dispersing. The ring was removed after a few days.

General experimental set-up: Each field experiment consisted of a number of $15.5 \mathrm{~cm}$-diameter plots. Treatment replicates $(7$ to 10 replicates, depending on the experiment) were arranged in rows on the sandflat, following a Latin-square design. Rows were oriented parallel to the shoreline, with 5 to $10 \mathrm{~m}$ between adjacent rows, and with each replicate within a row separated by $5 \mathrm{~m}$. Details of the treatments used for each experiment are given below.

Plots were established during low tide. Previous experimental work had shown that adding terrestrial sediment to the sandflat when it is covered or uncovered by the tide has no effect on macrofaunal recolonisation (Cummings et al. 2003). For terrestrial sediment treatments, a $15.5 \mathrm{~cm}$ (internal diameter), $3 \mathrm{~cm}$-deep PVC ring was pushed into the sediment so that $1 \mathrm{~cm}$ protruded above the surface. Sediment from the source plot was collected using a small trowel, and the ring was filled to the top. The ring was then carefully removed, leaving a $1 \mathrm{~cm}$-deep layer of terrestrial sediment. For natural sandflat sediment treatments, rings were pushed into the sediment and then removed, to mark the edges of the plots. Only the terrestrial sediment treatment plots were elevated, and not the 'control' natural sandflat treatment plots, because (1) elevation is a real phenomena associated with terrestrial sediment deposits, and (2) we wanted to retain the natural structure (physical and biological) of the sandflat sediments without creating a disturbance artefact. In addition, the hydrodynamic environment of the sandflat is naturally turbulent and dominated by small, and often breaking, wind-waves: under such conditions, we do not consider that any modification to boundary flow over the elevated plots would affect bivalve responses. Marked bivalves were added to each plot. Marking the bivalves (with non-toxic spray paint or a permanent marker pen) enabled us to distinguish individuals which we had added to the plots from those which might have moved in from outside, or were already resident in the natural sandflat treatments. Neither method of marking appeared to affect bivalve behaviour, and both had been used successfully in previous experiments (Thrush et al. 1997).

For each sediment type used in the experiments, 'netcovered' (2 $\mathrm{mm}$ mesh) treatments were also included. These nets controlled for natural movement (due to erosion or behaviour) of the bivalves away from the plots, and enabled us to assess burrowing of the juveniles in the field. Nets consisted of mesh circles of the same diameter as the plots, with $5 \mathrm{~cm}$-high walls. They were carefully pushed into the sediment so that they protruded $2 \mathrm{~cm}$ above the treatment surface, and were pegged down to prevent them being washed away. The nets used in the experiment failed to produce the commonly reported artefacts of increased deposition of fine sediments indicative of dampened flow conditions. Sediment ripples, symptomatic of bedload transport, migrated through the caged plots without modification. The edges of plots without nets ('uncovered' plots) were marked with small metal pegs. Net-covered treatments were never statistically compared with uncovered treatments (see subsection 'Statistical analyses' below).

Plots were left undisturbed for approximately $24 \mathrm{~h}$ (1 tidal cycle), after which time the following observations were made: (1) numbers of marked bivalves on the plot surface; (2) numbers of marked bivalves buried inside the plot; (3) numbers of marked bivalves which had left the plots (this number included individuals found on the sediment surface outside the plot 
(within a $10 \mathrm{~cm}$ perimeter), individuals buried outside the plot (within a $10 \mathrm{~cm}$ perimeter), and individuals which were not recovered at all). These numbers are presented as a percentage of the number of individuals added to the plots (mean $+\mathrm{SE}$ ).

Paphies australis experiments: We conducted 3 separate experiments using terrestrial sediment from the source plot, 0,7 and $28 \mathrm{~d}$ after it was deposited on the sandflat (Expt 1A, B, C, respectively); 10 replicates of each of the following treatments were used: uncovered terrestrial sediment, net-covered terrestrial sediment, uncovered natural sandflat, and net-covered natural sandflat. We added 10 marked Paphies australis to each replicate plot. The sizes of the $P$. australis used in this series of experiments ranged from 4 to $20 \mathrm{~mm}$, with mean shell lengths $( \pm \mathrm{SE})$ of $9.6( \pm 0.1), 9.8( \pm 0.1)$ and $10.6( \pm 0.1) \mathrm{mm}$, in the 0,7 and $28 \mathrm{~d}$ experiments, respectively.

The results of these 3 experiments differed, with the strongest juvenile Paphies australis response noted when the terrestrial sediment was 'new' (i.e. 0 d). To confirm that the different results were in fact due to the ageing of the source plot terrestrial sediment, and not just an artefact of differences in the experimental conditions and/or $P$. australis used on the different experimental dates, an additional experiment was conducted (Expt 2) that incorporated both 'new' and 'aged' terrestrial sediment treatments. The following 6 treatments were used in this experiment: new terrestrial sediment (uncovered), new terrestrial sediment (net-covered), aged terrestrial sediment (uncovered), aged terrestrial sediment (net-covered), natural sandflat (uncovered), and natural sandflat (net-covered).

The terrestrial sediment was sourced and mixed with seawater in the same way as described for the initial 3 Paphies australis experiments. The 'new' terrestrial sediment treatment was mixed with seawater on the same day as the experiment was set up. The 'aged' terrestrial sediment had been placed in a 'source plot' on the sandflat $18 \mathrm{~d}$ earlier. Seven replicates of each treatment were established, and 9 individuals (4.5 to $19.5 \mathrm{~mm}$ shell length; mean $\pm \mathrm{SE}=10.9 \pm 0.2 \mathrm{~mm}$ ) were added to each replicate. All other aspects of this experiment were identical to those described above for the initial $P$. australis experiments.

Macomona liliana aged terrestrial sediment experiment: The treatments used in the Macomona liliana experiment were the same as those described for the Paphies australis aged terrestrial sediment experiment, except that the aged terrestrial sediment had been placed in a source plot on the sandflat $28 \mathrm{~d}$ earlier. We added $10 \mathrm{M}$. liliana (3 to $9 \mathrm{~mm}$ shell length; mean $\pm \mathrm{SE}=4.8 \pm 0.06 \mathrm{~mm}$ ) to each replicate.

Statistical analyses. Laboratory experiments: The significance of differences between treatments in the
Paphies australis and Macomona liliana burrowing and reburrowing responses were tested using repeated-measures ANOVA (Green 1993) (PROC GLM, SAS Institute 1999). The normality and homogeneity of variance of the data was first assessed using Shapiro-Wilk and F-max tests, respectively; when data did not meet these assumptions, analyses were conducted on rank-transformed data. Differences between treatment means were assessed using Duncan or Tukey tests. If a significant interaction term was detected, the analysis was conducted separately for each time.

Field experiments: For each experiment, differences between the net-covered treatments were analysed separately from the uncovered treatments. These 2 treatment types investigated different aspects of the bivalve's behaviour: the covered plots were essentially a test of juvenile burrowing in the field, whilst the uncovered plots incorporated juvenile dispersal (via erosion or behaviour). In addition, the major response variable for the uncovered treatments (i.e. the percentage of individuals which had left the plots) was not a response variable for covered plots. Each data set was tested for normality and homogeneity of variance, and rank-transformed if appropriate, as described above for the laboratory experiments. Differences between treatments were tested using ANOVA (PROC $t$-test or PROC GLM, SAS Institute 1999). Analyses were conducted on the variables described above in the general experimental setup (i.e. \% of marked bivalves on the plot surface, buried inside the plot, and missing from the plots).

\section{RESULTS}

\section{Paphies australis laboratory experiments}

Normality tests of the burrowing and reburrowing responses of Paphies australis after 2, 4 and $20 \mathrm{~h}$ (Expt 1) and 2, 4 and $12 \mathrm{~h}$ (Expt 2) revealed that all data were non-normally distributed; thus data were ranktransformed prior to analysis. Because of significant treatment $\times$ time interaction terms (Expt 1: burrowing $\mathrm{p}<0.0001, \mathrm{df}=6, F=8.1$; reburrowing $\mathrm{p}<0.0001, \mathrm{df}=$ $6, F=34.7$; Expt 2: burrowing $\mathrm{p}=0.0005, F=6.4, \mathrm{df}=$ 6 ; reburrowing $\mathrm{p}=0.0446, \mathrm{df}=6, F=2.7$ ), the analyses were conducted separately for each time.

\section{Initial burrowing}

Paphies australis Expt 1. Expt 1 compared burrowing into control sand and 0.5 and $1.0 \mathrm{~cm}$-thick surface terrestrial sediment layers (Table 1). Paphies australis 
Table 1. Summary of laboratory experiments; 10 replicates of each treatment were used in each experiment. $0.5 \mathrm{~cm}$ layered: $0.5 \mathrm{~cm}$-thick terrestrial sediment layer covered with $0.5 \mathrm{~cm}$ layer of control sand. N: no. of bivalves per replicate. Numbers in square brackets: mean of size range

\begin{tabular}{|c|c|c|c|c|c|c|c|c|c|}
\hline \multicolumn{2}{|c|}{ Laboratory experiments } & \multicolumn{4}{|c|}{-Terrestrial sediment- } & \multirow{2}{*}{$\begin{array}{c}\text { Control sand } \\
+ \text { bivalve source }\end{array}$} & \multirow[t]{2}{*}{$\mathrm{N}$} & \multirow{2}{*}{$\begin{array}{l}\text { Size range } \\
(\mathrm{mm})\end{array}$} & \multirow{2}{*}{$\begin{array}{c}\text { Observations } \\
\text { (h) }\end{array}$} \\
\hline & & $\begin{array}{c}1 \mathrm{~cm} \\
\text { surface }\end{array}$ & $\begin{array}{c}0.5 \mathrm{~cm} \\
\text { surface }\end{array}$ & $\begin{array}{l}0.5 \mathrm{~cm} \\
\text { layered }\end{array}$ & $\begin{array}{c}\text { Source } \\
\text { catchment }\end{array}$ & & & & \\
\hline \multirow[t]{2}{*}{ Paphies australis } & Expt 1 & + & + & & Whitianga & Whitianga & 5 & $6-16[5]$ & $2,4,20$ \\
\hline & Expt 2 & & & + & Whitianga & Whitianga & 5 & $8-15[5]$ & $2,4,12$ \\
\hline Macomona liliana & & & + & + & Whitford & Manukau & 10 & $1.5-3.6[2.4]$ & $2,4,20$ \\
\hline
\end{tabular}

burrowed very slowly into the surface terrestrial sediment treatments compared to the control sand at all times, with significant differences between all 3 treatments after $20 \mathrm{~h}(4 \%$ remained on the surface of the control sand, and 80 and $98 \%$ on the surface of the 0.5 and $1.0 \mathrm{~cm}$ terrestrial sediment treatments, respectively; $\mathrm{p}<0.0001, \mathrm{df}=3, F=252.4$; Fig. 1A). Few $P$. australis had not burrowed into the control sand after $2 \mathrm{~h}$ $(16 \%)$.
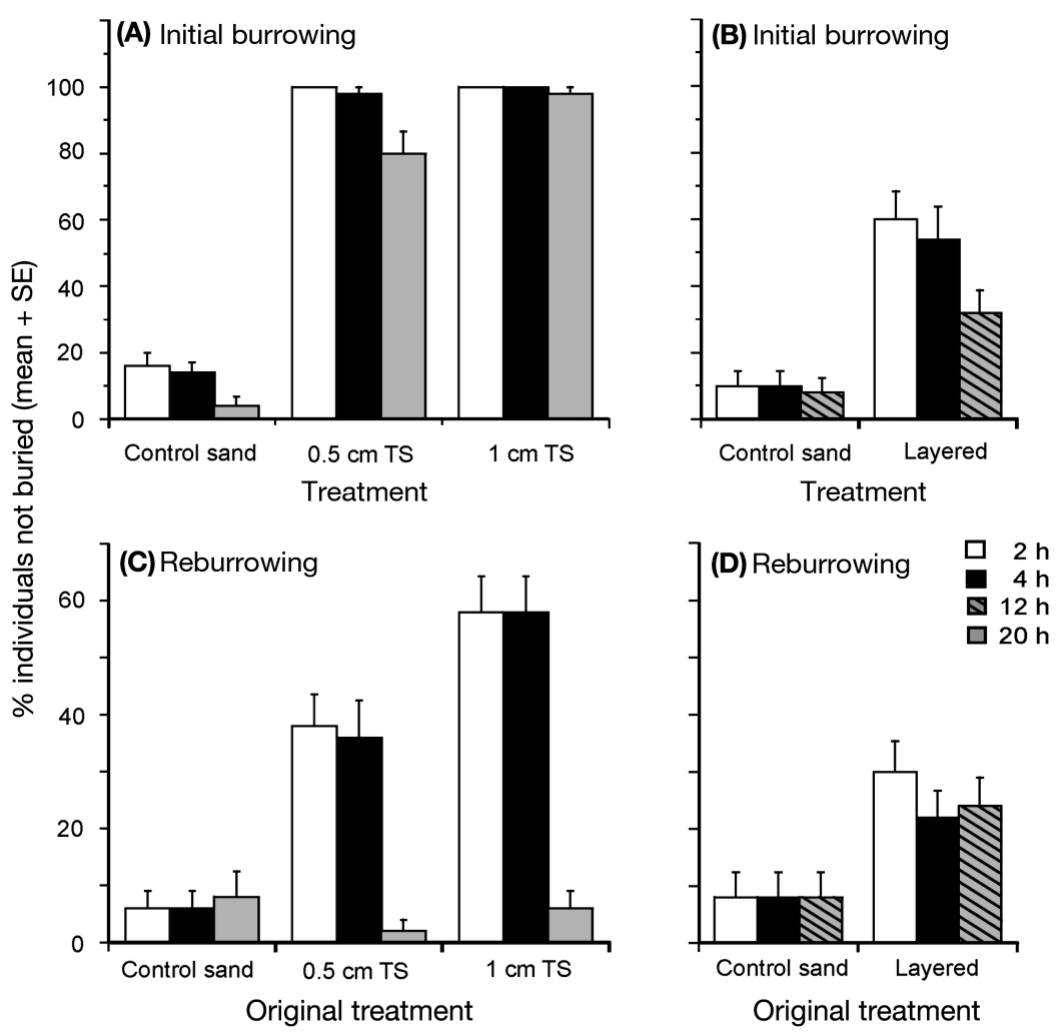

Fig. 1. Paphies australis. Initial burrowing and reburrowing of juveniles in terrestrial sediment (TS) in laboratory showing (A) initial burrowing into surface $(0.5$ and $1.0 \mathrm{~cm}$-thick) terrestrial sediment and control sand treatments, (B) initial burrowing into layered $(0.5 \mathrm{~cm}$ terrestrial sediment covered by $0.5 \mathrm{~cm}$ control sand) and control sand treatments, and $(C, D)$ reburrowing of same individuals subsequently introduced in control sand
Paphies australis Expt 2. Expt 2 compared burrowing in control sand and submerged $0.5 \mathrm{~cm}$-thick terrestrial sediment layer (Table 1). As in the first experiment, Paphies australis rapidly burrowed into the control sand (only $10 \%$ remained on the surface after $2 \mathrm{~h}$ ). However, they were slower to burrow in the layered terrestrial sediment treatment, with significantly more on the sediment surface at all times (60 to $32 \%$; p < $0.0001, \mathrm{df}=2 ; F=74.8$ after $2 \mathrm{~h} ; \mathrm{p}<0.0001, \mathrm{df}=2$; $F=70.3$ after $4 h_{i} \mathrm{p}<0.0001$, df $=2 ; F=$ 87.2 after $12 h_{;}$Fig. 1B). In comparison to the surface terrestrial sediment treatments, burrowing in the treatment with submerged terrestrial sediment was relatively high (cf. Fig. 1A,B).

\section{Reburrowing}

In both experiments, the Paphies australis which had been exposed to the terrestrial sediment treatments were slower reburrowing into control sand than those exposed only to control sand (Fig. 1C,D). In addition, in Expt 1, exposure to the $1 \mathrm{~cm}$ surface terrestrial sediment layer appears to have slowed the reburrowing ability of the $P$. australis more than exposure to the $0.5 \mathrm{~cm}$ layer, as significantly more individuals originating from the former treatment remained on the sediment surface after $4 \mathrm{~h}$ (58\% compared to $38 \%$ in the $0.5 \mathrm{~cm}$ treatment; $\mathrm{p}<0.0001$, df $=3, F=79.9$; Fig. 1C). After 20 h, there were no significant differences between treatments. In Expt 2, significantly more of the individuals originating from the submerged $0.5 \mathrm{~cm}$ terrestrial sediment treatment remained on the surface after $12 \mathrm{~h}(24 \%)$ than individuals originating from the control sand treatment $(8 \% ; \mathrm{p}<0.0001, \mathrm{df}=2$, $F=47.6$; Fig. 1D). 


\section{Macomona liliana laboratory experiment}

Initial burrowing

The majority of the Macomona liliana burrowed quickly in the control sand, with only $3 \%$ of individuals still remaining on the surface after $2 \mathrm{~h}$ (Fig. 2A). Conversely, there was practically no burrowing in the $0.5 \mathrm{~cm}$ surface terrestrial sediment treatment, even after 20 h (i.e. $95 \%$ remained on the surface; Fig. 2A). The response of individuals to the submerged terrestrial sediment treatment was initially more similar to that of the control sand, with no significant difference between these 2 treatments after $2 \mathrm{~h}$. Interestingly however, the numbers of $M$. liliana on the surface of the submerged sediment treatment increased over the experiment, and after 4 and $20 \mathrm{~h}$ were significantly higher than in the controls $(\mathrm{p}<0.0001, \mathrm{df}=3, F=208.1$ after $4 h_{i} p<0.0001$, df $=3, F=306.0$ after $20 h_{\text {; }}$ Fig. 2A).

\section{Reburrowing}

Macomona liliana originating from the surface terrestrial sediment treatment were slowest to reburrow into control sand (Fig. 2B). There were significant differences between all treatments in numbers buried after 2 and $4 \mathrm{~h}(\mathrm{p}<0.0001, \mathrm{df}=3, F=88.9$ after $2 \mathrm{~h}$; $\mathrm{p}<$ $0.0001, \mathrm{df}=3, F=90.2$ after $4 \mathrm{~h})$. After $20 \mathrm{~h}$, significant differences were detected between the surface terrestrial sediment and control treatments only (8.3 and $0 \%$, respectively; $\mathrm{p}<0.0001, \mathrm{df}=3, F=58.4)$.

\section{Paphies australis field experiments}

\section{Expt 1A: newly deposited terrestrial sediment (0 d)}

At the end of this field experiment, more individuals were found on the surface of the terrestrial sediment treatment than in the natural sandflat treatment in both the uncovered and net-covered plots $(\mathrm{p}=0.0002$, $\mathrm{df}=11.2, t=-5.4$ for uncovered plots; $\mathrm{p}=0.0003, \mathrm{df}=$ $19, t=4.4$ for net-covered plots; Fig. 3A and D, respectively). In addition, more Paphies australis had buried into the natural sandflat in both cases $(\mathrm{p}=0.0008, \mathrm{df}=$ $19, t=4.0$ for uncovered plots; $\mathrm{p}=0.0003, \mathrm{df}=19, t=$ -4.4 for net-covered plots). There was no difference between treatments in the percentage of individuals which left the uncovered plots $(\mathrm{p}=0.8613, \mathrm{df}=19, t=$ 0.2 ; Fig. 3A).

Expt 1B: aged terrestrial sediment ( $7 \mathrm{~d}$ )

The response of Paphies australis to terrestrial sediment that had been on the sandflat for $1 \mathrm{wk}$ was slightly different to that described above for newly deposited terrestrial sediment. Few individuals were found on the surface of any of the plots at the end of the experiment $(\leq 15 \%$; Fig. 3B,E). There were no significant differences between treatments for either response variable in the net-covered treatments $(\mathrm{p}=$ 0.0652 , df $=18, t=2.0$ for $\%$ individuals on the plot surface, and $\mathrm{p}=0.3506$, df $=18, t=-1.0$ for $\%$ buried individuals; Fig. 3E). In the uncovered plots, however, more $P$. australis had burrowed into the natural sandflat than into the terrestrial sediments (70 and $43 \%$, respectively; $\mathrm{p}=0.0362$, $\mathrm{df}=18, t=2.3$; Fig. $3 \mathrm{~B}$ ). The natural movement of $P$. australis away from the uncovered plots was higher in this experiment, and significantly more individuals left the terrestrial sediments than the natural sandflat (46 and 19\%, respectively; $\mathrm{p}=0.0423, \mathrm{df}=18, t=-2.2 ;$ Fig. 3B).

\section{Expt 1C: aged terrestrial sediment $(28 \mathrm{~d})$}

This experiment used terrestrial sediment that had been on the sandflat for almost 1 mo. In the uncovered plots, fewer individuals had burrowed in the terrestrial sediments than in the natural sandflat (53 and $74 \%$ respectively; Fig. $3 C_{i} \mathrm{p}=0.0079$, df $=18, t=3.0$ ) and
Fig. 2. Macomona liliana. (A) Initial burrowing of juveniles in surface $(0.5 \mathrm{~cm}$-thick $)$ and layered $(0.5 \mathrm{~cm}$ terrestrial sediment covered by $0.5 \mathrm{~cm}$ of control sand) terrestrial sediments (TS) and control sand in laboratory; (B) reburrowing of same individuals subsequently introduced into control sand
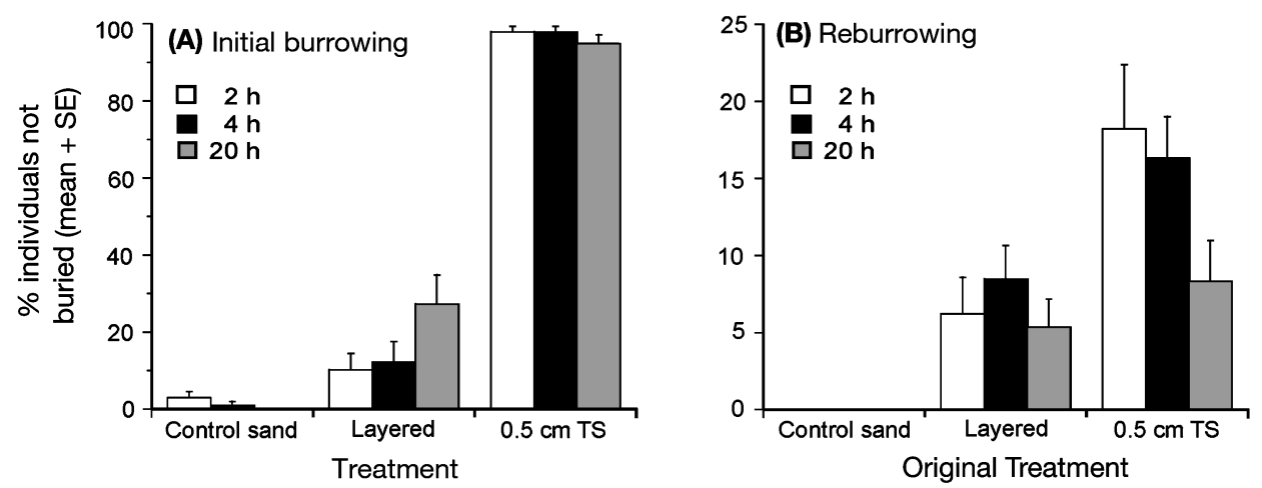

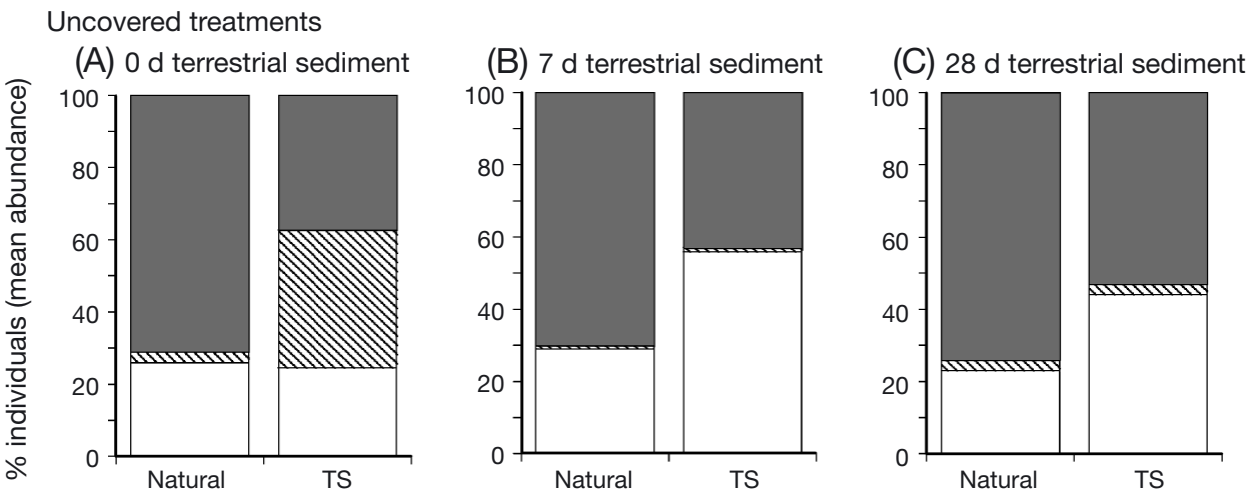

Net-covered treatments

(D) 0 d terrestrial sediment

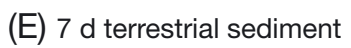

(F) 28 d terrestrial sediment
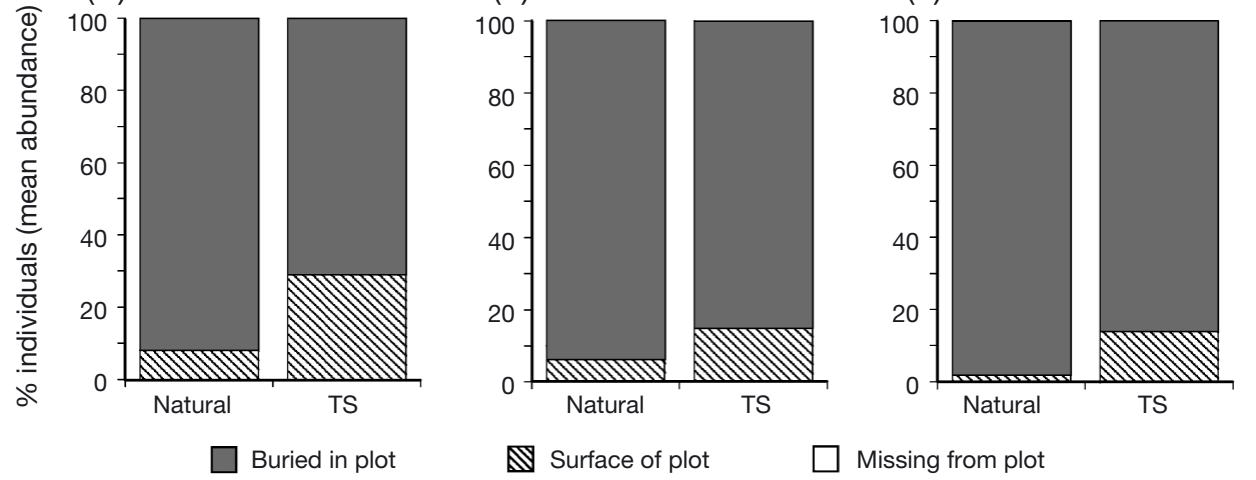

Fig. 3. Paphies australis. Response of juvenile $P$. australis to surface $(1.0 \mathrm{~cm}$ thick) terrestrial sediment (TS) in (A-C) uncovered and (D-F) net-covered experiments in the field. Results of separate experiments, using terrestrial sediment that had been 'aged' for 0,7 and $28 \mathrm{~d}$ on the sandflat as indicated. Natural: natural sandflat sediments

more individuals had left the terrestrial sediments $(44$ and $23 \%$ in the sandflat; Fig. $3 C_{i} p=0.0040$, df $=18$, $t=-3.3$ ). No differences were detected between treatments in the numbers of Paphies australis on the surface of either the uncovered or net-covered plots $(\mathrm{p}=$ $1.0000, \mathrm{df}=18, t=0.0$ for uncovered plots; $\mathrm{p}=0.0798$, $\mathrm{df}=9.9, t=2.0$ for net-covered plots), or in the numbers buried in the net-covered treatments $(\mathrm{p}=0.0735$, df $=$ 10.2, $t=-2.0$; Fig. 3F).

Expt 2: new versus aged terrestrial sediment experiment ( 0 and $18 d$, respectively)

The natural movement of Paphies australis from the uncovered plots was very high in this experiment. All the individuals added to the new and aged terrestrial sediment treatments were either found outside the plots at the end of the experiment, or were not recovered (Fig. 4A). Consequently, we detected a significant difference in the percentage of individuals that had burrowed in the plots, with $10 \%$ buried in the natural sandflat plots only ( $p=0.0036$, $d f=2, F=7.8$; Fig. 4A). This high movement from all treatments is likely to be at least partially due to the stormy weather prevalent during this experiment, and the small size of the experimental plots.

There was comparatively high burrowing activitiy in all net-covered treatments; more Paphies australis had burrowed in the natural sandflat and aged terrestrial sediment treatments than in the new terrestrial sediment treatment $(>90$ and $73 \%$, respectively; $\mathrm{p}=$ 0.0271, $\mathrm{df}=2, F=4.4$; Fig. 4B). In addition, there were significant differences between all treatments in the percentage of individuals found on the plot surface, with most on the new terrestrial sediments $(25 \%)$ and least on the natural sandflat sediments $(0 \%$; $=0.0006$, df $=2, F=11.4$; Fig. 4B).

\section{Macomona liliana field experiment: new versus aged terrestrial sediment experiment ( 0 and $28 \mathrm{~d}$, respectively)}

While many of the individuals added to the uncovered plots in this experiment were not recovered (Fig. 5A), conditions were calmer during this experiment in than in the Paphies australis experiment detailed above. There were significant differences in 
(A) Uncovered treatments

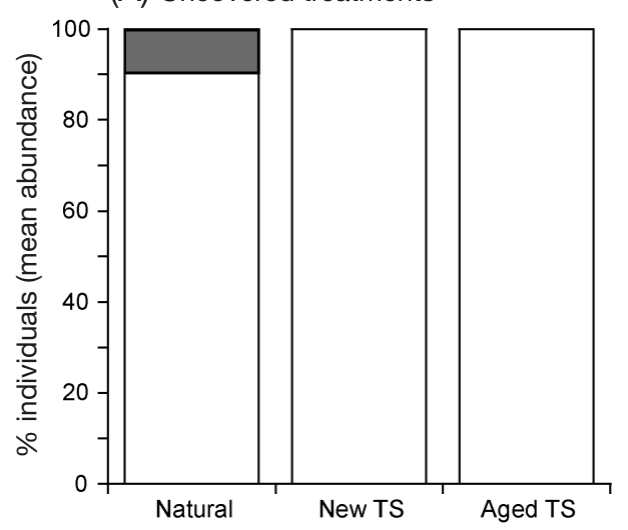

Buried in plot $\mathbb{Q}$ Surface of plot $\square$ Missing from plot

(B) Net-covered treatments

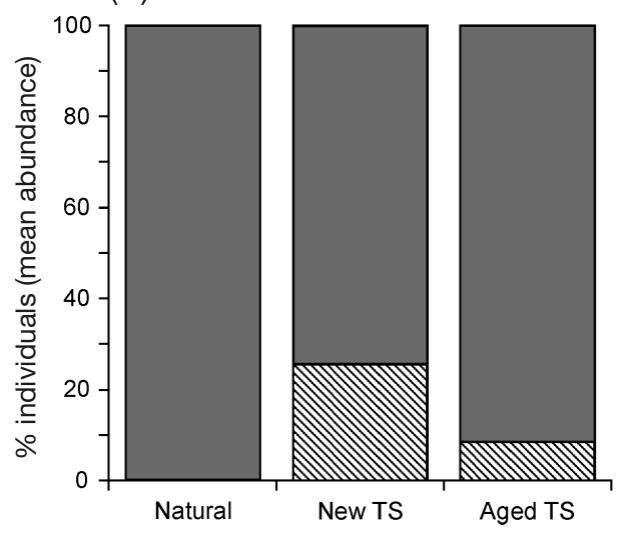

Fig. 4. Paphies australis. Response of juvenile $P$. australis to surface $(1.0 \mathrm{~cm}$ thick) terrestrial sediment in (A) uncovered and (B) net-covered experiments in field, comparing responses to natural sandflat sediments (Natural) and new (0 d) and aged (18 d) terrestrial sediment (TS)

the percentage of individuals that had left the plots, with fewest missing from the new terrestrial sediments $(33 \% ; \mathrm{p}=0.0252, \mathrm{df}=2, F=4.6$; Fig. 5A). Interestingly, a high number of the Macomona liliana which remained in the new terrestrial sediment were found on the plot surface ( $44 \%$; Fig. $5 \mathrm{~A}$ ): significantly more than were found on the surface of the other treatments $(0 \%$ for natural sandflat, $10 \%$ for aged terrestrial sediment; $\mathrm{p}<0.0001, \mathrm{df}=2, F=38.4$ ). There were no differences between treatments in the number of individuals that had burrowed in the uncovered plots $(p=0.6209$, $\mathrm{df}=2, F=0.5$ ).

A similar, but stronger, pattern in Macomona liliana's behaviour was noted for the covered treatment plots. There were significant differences between all treatments in the M. liliana recovered from the plot surface, with most found on the surface of the new terrestrial sediment treatment $(74 \%)$, and least on the natural sandflat $(1 \% ; \mathrm{p}<0.0001, \mathrm{df}=2, F=49.1$; Fig. 5B). Bur- rowing in the plots was also significantly different between all treatments, with most $M$. liliana burrowing into the natural sandflat $(94 \%)$, and least into the new terrestrial sediments $(21 \% ; \mathrm{p}<0.0001, \mathrm{df}=2, F=67.7$; Fig. 5B).

\section{DISCUSSION}

Previous investigations of the recovery of intertidal sandflats from storm-associated deposition of terrestrial sediment have demonstrated slow recolonisation of the impacted areas by macrofauna (Norkko et al. 2002, Cummings et al. 2003, Hewitt et al. 2003, Thrush et al. 2003). Although sampling of experimental plots was conducted over periods from 212 to $603 \mathrm{~d}$ in the different experiments, complete recovery was never observed. Juveniles did not colonise the terrestrial sediments, indicating that those that did settle were quickly consumed by predators, that they left

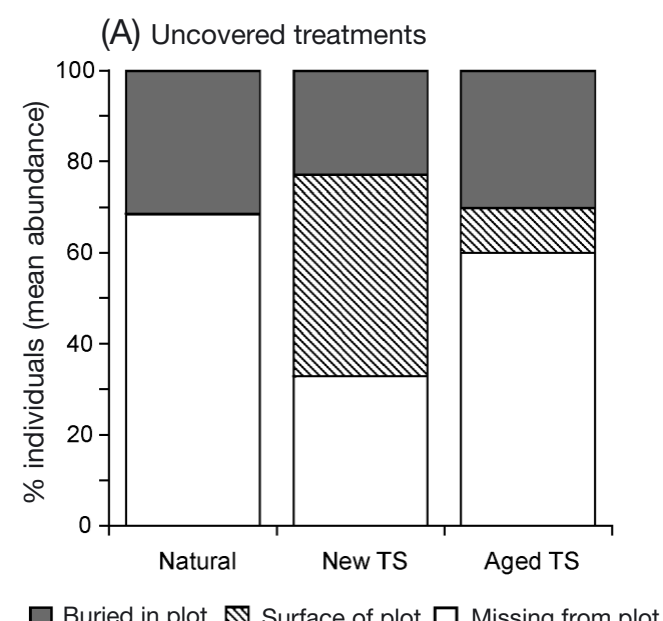

(B) Net-covered treatments

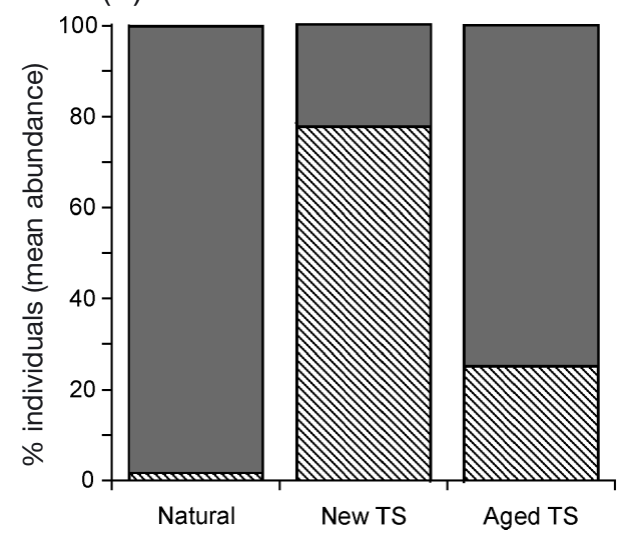

Fig. 5. Macomona liliana. Response of juveniles to surface $(1.0 \mathrm{~cm}$ thick) terrestrial sediment in (A) uncovered and (B) net-covered experiments in the field, comparing responses to natural sandflat sediments (Natural) and new $(0 \mathrm{~d})$, and aged (28 d) terrestrial sediment (TS) 
quickly and dispersed to more suitable habitats, or that they avoided settling in the deposits. The current study has demonstrated that, for juveniles of 2 common and ecologically important bivalves, exposure to surface and submerged layers of terrestrial sediments slows their burrowing rates, and the effect of this exposure persists even when the juveniles are subsequently introduced to more suitable sediments (Figs. 1 \& 2). Behaviour associated with burrowing into and dispersal from terrestrial deposits in the field was changed for both species, although these behavioural responses weakened with increasing length of time the deposits had remained on the sandflat (Figs. 3 to 5). These results provide some insight into the extremely low rate of recovery by macrobenthic communities following the deposition of terrestrial sediments, and the potential consequences this may have for juvenile bivalves dispersing across disturbed landscapes.

The responses of the juvenile bivalves observed in our experiments demonstrate active choice in the face of unfavourable conditions. In the laboratory, behavioural responses were elicited when the juveniles were exposed to either surface or submerged layers $(0.5 \mathrm{~cm}$ thick) of terrestrial sediment, although both Paphies australis and Macomona liliana exhibited a slightly stronger response to surface layers. These results provide an important mechanistic clue, at least for the small $M$. liliana (maximum shell length in these experiments $=3.6 \mathrm{~mm}$ ): any mechanical difficulties they may face when burrowing directly into the surface terrestrial sediment (due, for example, to different geotechnical properties) would not affect juveniles burrowing into the treatments covered by a surface layer of sand (i.e. submerged layer). This suggests that the juveniles are responding to the presence, or absence, of chemical/biogeochemical cues originating directly from the terrestrial sediment. Woodin et al. (1995) found similar effects on the burrowing ability of juvenile macrofauna in a series of short-term (several minutes) laboratory experiments that simulated burrowing or removal of the top several millimetres of sediment. Burrowing times of juvenile Arenicola cristata and Mercenaria mercenaria were significantly slower on recently disturbed surfaces than on undisturbed surfaces and, in flow conditions, those juveniles that had not burrowedwere quickly eroded off the sediment surface (Woodin et al. 1995). These responses were attributed to the ability of the recruits to detect disruptions in gradients of various porewater solutes (e.g. oxygen, ammonium; Woodin 1998, Marinelli \& Woodin 2002). The relationship between benthic organisms and sediments is complex, due in part to the large number of variables which define the sediment characteristics (e.g. grain size, organic content, pore- water solutes etc.; see Gray 1974, Snelgrove \& Butman 1994), and the continual modification of these characteristics both by environmental variables (e.g. hydrodynamics) and biological processes. We have previously documented persistent differences in food (i.e. chlorophyll a; carbohydrate), $\mathrm{P}$ and $\mathrm{N}$ content, and grain size between terrestrial deposits and natural sandflats (Cummings et al. 2003). These latter measurements were made over a 4 mo period, in much thicker deposits (i.e. $10 \mathrm{~cm}$ deep) than those used in this experiment. While the cues discussed above are likely to be detectable by recruits encountering the sediment surface, the ability of individuals to detect the presence, or absence, of gradients higher in the water column is not yet well known (e.g. Finelli et al. 1999, Jumars et al. 2001).

Several field experiments were conducted to determine the effect on juvenile bivalve behaviour of terrestrial sediment that had been aged to varying degrees on the sandflat. We had expected that in the uncovered plots the Paphies australis and Macomona liliana juveniles would drift off unsuitable sediments. However, these experiments demonstrated that movement and burrowing of $M$. liliana was strongly affected by new terrestrial sediment: several individuals remained on the surface of the uncovered $0 \mathrm{~d}$ plots and did not disperse away from it (Fig. 5A), indicating that the 'new' terrestrial sediment had somehow modified their behaviour. $M$. liliana in the field were seemingly unable to leave the terrestrial sediment deposits once they had encountered them. This suggestion of behavioural modification influencing dispersal ability is supported by field observations of mass dispersal of $M$. liliana in response to pesticide application (Pridmore et al. 1991), and by a previous laboratory-based flume experiment that demonstrated that $M$. liliana are able to choose between 'favourable' sediments and 'unfavourable' (ambient sandflat and dense spionid polychaete tube mat: Cummings et al. 1996). There is also a suggestion of similar effects of new terrestrial sediment on Paphies australis (Fig. 3A), although the stormy conditions and consequent nil recovery of $P$. australis in the final field experiment prevented confirmation of this (Fig. 4). Nevertheless, $P$. australis will preferentially move away from terrestrial sediments, even when the sediments have been on the sandflat for some time (e.g. Fig. 3B,C). The behaviour of both species was significantly affected by aged terrestrial sediment, although not to the same extent as by the new terrestrial sediment (Figs. 4 \& 5). It is important to note that any species-specific differences in our results may have been influenced by the different-sized individuals used in the experiments, particularly because of the thinness of the terrestrial sediment layers. However, our exper- 
iments have clearly illustrated that settlement in terrestrial sediment deposits at some sites may be lethal or have significant detrimental effects on bivalve health, implying that an ability to detect the (un)suitability of these substrates prior to settlement would be an advantage to the juveniles.

The negative response to 'new' deposits observed in these experiments may in part be due to $\mathrm{pH}$, since terrestrial sediments initially have a lower $\mathrm{pH}$ than sandflat sediments $(\sim 4$, measured using a combination needle $\mathrm{pH}$ electrode [Diamond General Development] linked to an Orion 290A multimeter). However, the $\mathrm{pH}$ becomes neutralised relatively rapidly (after 1 to 2 tidal cycles; Lohrer et al. 2004, V. Cummings \& M. Ahrens unpubl. obs.). Another difference between new and aged terrestrial sediment is the degree of mixing the latter has undergone with the ambient sandflat sediment. Thinner terrestrial sediment deposits may become gradually buried by sediments transported from the surrounding sandflat with bedload (Hewitt et al. 2003, Thrush et al. 2003), or become incorporated into the sandflat sediments by bioturbators such as crabs and shrimps (e.g. Norkko et al. 2002, Cummings et al. 2003). As the terrestrial sediment 'ages' on the sandflat, there is a gradual decline in the proportion of silt and clay, and an increase in the amount of sand. This sand has different physical and chemical characteristics, and will modify any cues diffusing out of the submerged terrestrial sediment. Whatever the mechanism, it is clear that the longer the deposits have been exposed to the natural estuarine environment, the more likely they are to become colonised.

Many studies have shown that post-settlement macrofauna introduced to unfavourable sediments will avoid burrowing, and will often disperse in flow. For example, post-larvae of the bivalve Spisula solidissima demonstrate active choice of sediments characteristic of their natural habitat in flow conditions (Snelgrove et al. 1999), as do Macoma balthica and Cerastoderma edule (de Montaudoin 1997, Huxham \& Richards 2003), the polychaetes Pectinaria koreni (Olivier et al. 1996b) and Capitella sp. (Hsieh \& Hsu 1999) and the oligochaetes Paranais litoralis (Nilsson et al. 2000) and Doliodrilus tener (Hsieh \& Hsu 1999). The consensus of these studies was that these individuals could not choose the sediment on which they alight, but that they were able to leave less-preferred sediments in a series of migrations until the preferred habitat was found (Olivier et al. 1996b, Nilsson et al. 2000, Huxham \& Richards 2003). If, however, as in our experiments, an individual's settlement history limits potential for re-dispersal, then settlement avoidance is an adaptative advantage. While the ability of larvae to settle and metamorphose in response to waterborne cues has been demonstrated for a variety of benthic invertebrate species (e.g. Pawlik 1992, Lambert \& Todd 1994, Zimmer-Faust \& Tamburri 1994, Tamburri et al. 1996, Krug \& Zimmer 2000, Zimmer \& Butman 2000), this has yet to be extensively proved for post larval stages. More work is required to determine whether Paphies australis or Macomona liliana need to settle to determine habitat suitability, and whether they have the sensory capacity to detect waterborne cues. It is likely that from an evolutionary perspective the ability of dispersing juveniles to detect suitable habitats prior to 'landing' would be even more important than for dispersing larvae, given the far fewer numbers of the former and thus their greater need to maximise their survival.

Most soft-sediment organisms in estuaries and embayments are restricted in their dispersal abilities and are subject to local dispersal processes; transport between habitats (e.g. channels, sandflats) is limited (Lundquist et al. 2004). Thus if a terrestrial deposit covers a large portion of a sandflat, or even only half of a sandflat, a juvenile bivalve may potentially encounter the unfavourable surface several times before a suitable substrate is found, and this exposure will have implications for its fitness and survival. Similarly, deposition of thin layers of terrestrial sediment occurs frequently in some intertidal areas around New Zealand (e.g. Lohrer et al. 2004). While deposition of these thin layers may not be as visually obvious or as devastating to the existing macrofaunal community as deposition of thicker layers, these experiments have shown that even after the terrestrial sediments are subsequently buried by sandflat sediments they will affect potential bivalve colonists. Depending on the extent and frequency of disturbance, there are likely to be important implications for the population and community dynamics.

In conclusion, this study has demonstrated a negative effect of terrestrial sediment deposits on colonisation by juvenile bivalves. Our laboratory experiments have shown that exposure to terrestrial sediments affects the burrowing and reburrowing ability of Paphies australis and Macomona liliana, that these effects persist even with reasonably thin $(0.5 \mathrm{~cm})$ surface layers of terrestrial sediment, and even after they have been covered by sediment from the surrounding sandflat (layered treatments). This effect on reburrowing ability is important, as it suggests that settlement on terrestrial sediment deposits can have a lasting effect even if an individual is able to find a more suitable habitat at a later date. Our field experiments have shown that $M$. liliana encountering $1 \mathrm{~cm}$-thick terrestrial sediment deposits in the natural environment are less able to leave these sediments, and that this effect is evident even after the sediment has been 
on the sandflat for 1 mo. These individuals are therefore essentially lost from the pool of available colonists. Finally, this study has provided further evidence of the importance of good catchment-management practices to avoid sedimentation events in the first place.

Acknowledgements. We thank J. Hewitt, G. Funnell, A. Norkko, and especially J. Norkko, for help in the field. This research was funded by the New Zealand Foundation for Research, Science and Technology (FRST-C01X0024 and FRST-C01X037) and NIWA-NSOF.

\section{LITERATURE CITED}

Airoldi L (2003) The effects of sedimentation on rocky coast assemblages. Oceanogr Mar Biol Annu Rev 41:161-236

Alongi DM (1998) Coastal ecosystem processes. CRC Press, Boca Raton, FL

Armonies W (1994) Turnover of postlarval bivalves in sediments of tidal flats in Königshafen (German Wadden Sea). Helgol Meeresunters 48:291-297

Baggerman B (1953) Spatfall and transport of Cardium edule L. Arch Néerl Zool 10:315-342

Butman C (1987) Larval settlement of soft-sediment invertebrates: the spatial scales of pattern explained by active habitat selection and the emerging role of hydrodynamical processes. Oceanogr Mar Biol Annu Rev 25:113-165

Cicin-Sain B, Bernal P, Vanderweers V, Belifiore S, Goldstein $\mathrm{K}$ (2002) Oceans, coasts and islands at the world summit on sustainable development and beyond. Center for the Study of Marine Policy, Newark, DE

Commito J, Currier C, Kane L, Reinsel K, Ulm I (1995) Dispersal dynamics of the bivalve Gemma gemma in a patchy environment. Ecol Monogr 65:1-20

Cummings VJ, Pridmore RD, Thrush SF, Hewitt JE (1993) Emergence and floating behaviours of post-settlement juveniles of Macomona liliana (Bivalvia: Tellinacea). Mar Behav Physiol 24:25-32

Cummings VJ, Pridmore RD, Thrush SF, Hewitt JE (1995) Post-settlement movement by intertidal benthic macrofauna: do common New Zealand species drift in the water column? NZ J Mar Freshw Res 29:59-67

Cummings VJ, Pridmore RD, Thrush SF, Hewitt JE (1996) Effect of the spionid polychaete Boccardia syrtis on the distribution and survival of juvenile Macomona liliana (Bivalvia: Tellinacea). Mar Biol 126:91-98

Cummings V, Thrush S, Hewitt J, Norkko A, Pickmere S (2003) Terrestrial deposits on intertidal sandflats: sediment characteristics as indicators of habitat suitability for recolonising macrofauna. Mar Ecol Prog Ser 253:39-54

de Montaudouin X (1997) Potential of bivalves' secondary settlement differs with species: a comparison between cockle (Cerastoderma edule) and clam (Ruditapes philippinarum) juvenile resuspension. Mar Biol 128:639-648

Duarte CM (2002) The future of seagrass meadows. Environ Conserv 29:192-206

Edgar GJ, Barrett NS (2000) Effects of catchment activities on macrofaunal assemblages in Tasmanian estuaries. Estuar Coast Shelf Sci 50:639-654

Ellis JI, Thrush SF, Norkko A (2000) Broad-scale disturbance of intertidal and shallow sublittoral soft-sediment habitats: effects on the benthic macrofauna. J Aquat Ecosyst Stress Recovery 7:57-74
Emerson C, Grant J (1991) The control of soft-shell clam (Mya arenaria) recruitment on intertidal sandflats by bedload sediment transport. Limnol Oceanogr 36:1288-1300

Finelli C, Pentcheff ND, Zimmer-Faust R, Wethey D (1999) Odor transport in turbulent flows: constraints on animal navigation. Limnol Oceanogr 44:1056-1071

Foster G, Carter L (1997) Mud sedimentation on the continental shelf at an accretionary margin-Poverty Bay, New Zealand. NZ J Geol Geophys 40:157-173

GESAMP (Group of Experts on the Scientific Aspects of Marine Environmental Protection) (1994) Anthropogenic influences on sediment discharge to the coastal zone and environmental consequences. UNESCO-TOC, Paris

Gibbs M, Thrush S, Ellis J (2001) Terrigenous clay deposition on estuarine sandflats: using stable isotopes to determine the role of the mud crab, Helice crassa Dana, in the recovery process. Isot Environ Health Stud 37:113-131

Gray JS (1974) Animal-sediment relationships. Oceanogr Mar Biol Annu Rev 12:223-261

Gray JS (1997) Marine biodiversity: patterns, threats and conservation needs. Biodivers Conserv 6:153-175

Green RH (1993) Application of repeated measures designs in environmental impact and monitoring studies. Aust J Ecol 18:81-98

Günther C (1992) Dispersal of intertidal invertebrates: a strategy to react to disturbances of different scales? Neth J Sea Res 30:45-56

Hewitt JE, Pridmore RD, Thrush SF, Cummings VJ (1997) Assessing the short-term stability of spatial patterns of macrobenthos in a dynamic estuarine system. Limnol Oceanogr 42:282-288

Hewitt JE, Cummings VJ, Ellis JI, Funnell G, Norkko A, Talley TS, Thrush SF (2003) The role of waves in the colonisation of terrestrial sediments deposited in the marine environment. J Exp Mar Biol Ecol 290:19-47

Hicks DM, Gomez B, Trustrum NA (2000) Erosion thresholds and suspended sediment yields, Waipaoa River Basin, New Zealand. Water Resour Res 36:1129-1142

Hooker SH (1995) Preliminary evidence for post-settlement movement of juvenile and adult pipi, Paphies australis (Gmelin, 1790) (Bivalvia: Mesodesmatidae). Mar Freshw Behav Physiol 27:37-47

Hooker SH, Creese RG (1995) The reproductive biology of pipi, Paphies australis (Gmelin, 1790) (Bivalvia: Mesodesmatidae). I. Temporal patterns of the reproductive cycle. J Shellfish Res 14:7-15

Hsieh HL, Hsu CF (1999) Differential recruitment of annelids onto tidal elevations in an estuarine mud flat. Mar Ecol Prog Ser 177:93-102

Hunt HL, Mullineaux LS (2002) The roles of predation and postlarval transport in recruitment of the soft shell clam (Mya arenaria). Limnol Oceanogr 47:151-164

Huxham M, Richards M (2003) Can postlarval bivalves select sediment type during settlement? A field test with $\mathrm{Ma}$ coma balthica (L.) and Cerastoderma edule (L.). J Exp Mar Biol Ecol 288:279-293

Jumars PA, Eckman JE, Koch E (2001) Macroscopic animals and plants in benthic flows. In: Boudreau BP, Jørgensen BB (eds) The benthic boundary layer. Transport processes and biogeochemistry. Oxford University Press, New York, p 320-347

Krug PJ, Zimmer RK (2000) Larval settlement: chemical markers for tracing production, transport, and distribution of a waterborne cue. Mar Ecol Prog Ser 207:283-296

Lambert WJ, Todd CD (1994) Evidence for a water-borne cue inducing metamorphosis in the dorid nudibranch mollusc Adalaria proxima (Gastropoda: Nudibranchia). Mar Biol 120:265-271 
Lohrer AM, Thrush SF, Hewitt JE, Berkenbusch K, Ahrens M, Cummings VJ (2004) Terrestrially derived sediment: response of marine macrobenthic communities to thin terrigenous deposits. Mar Ecol Prog Ser 273:121-138

Lundin CG, Linden O (1993) Coastal ecosystems: attempts to manage a threatened resource. Ambio 22:468-473

Lundquist CJ, Thrush SF, Oldman JW, Senior AK (2004) Limited transport and recolonization potential in shallow tidal estuaries. Limnol Oceanogr 49:386-395

Marinelli RL, Woodin SA (2002) Experimental evidence for linkages between infaunal recruitment, disturbance, and sediment surface chemistry. Limnol Oceanogr 47: 221-229

McClanahan TR, Obura D (1997) Sedimentation effects on shallow coral communities in Kenya. J Exp Mar Biol Ecol 209:103-122

McFarland VA, Peddicord RK (1980) Lethality of a suspended clay to a diverse selection of marine and estuarine macrofauna. Arch Environ Contam Toxicol 9:733-741

McKnight DG (1969) A recent, possibly catastrophic burial in a marine molluscan community. NZ J Mar Freshw Res 3: 177-179

Milliman JD, Meade RH (1983) World-wide delivery of river sediment to the oceans. J Geol 91:1-21

Moore PG (1977) Inorganic particulate suspensions in the sea and their effects on marine animals. Oceanogr Mar Biol Annu Rev 15:225-263

Nilsson PG, Levinton JS, Kurdziel JP (2000) Migration of a marine oligochaete: induction of dispersal and microhabitat choice. Mar Ecol Prog Ser 207:89-96

Norkko A, Cummings VJ, Thrush SF, Hewitt JE, Hume T (2001) Local dispersal of juvenile bivalves: implications for sandflat biology. Mar Ecol Prog Ser 212:131-144

Norkko A, Thrush SF, Hewitt JE, Cummings VJ and 5 others (2002) Smothering of estuarine sandflats by terrigenous clay: the role of wind-wave disturbance and bioturbation in site-dependent macrofaunal recovery. Mar Ecol Prog Ser 234:23-41

Olivier F, Desroy N, Retiere C (1996a) Habitat selection and adult-recruit interactions in Pectinaria koreni (Malmgren) (Annelida: polychaeta) post-larval populations: results of flume experiments. J Mar Res 36:217-226

Olivier F, Vallet C, Dauvin J, Retiere C (1996b) Drifting in post-larvae and juveniles in an Abra alba (Wood) community of the eastern part of the Bay of Seine (English Channel). J Exp Mar Biol Ecol 199:89-109

Pawlik JR (1992) Chemical ecology of the settlement of benthic marine invertebrates. Oceanogr Mar Biol Annu Rev 30:273-335

Peterson CH (1985) Patterns of lagoonal bivalve mortality after heavy sedimentation and their palaeoecological significance. Palaeobiology 11:139-153

Pridmore RD, Thrush SF, Wilcock RJ, Smith TJ, Hewitt JE, Cummings VJ (1991) Effect of the organochlorine pesti-

Editorial responsibility: John Gray (Contributing Editor), Oslo, Norway cide technical chlordane on the population structure of suspension and deposit feeding bivalves. Mar Ecol Prog Ser 69:245-252

SAS Institute (1999) SAS/STAT users guide. Version 8, Cary, NC

Scheltema R (1995) The relevance of passive dispersal for the biogeography of Caribbean mollusks. Am Malacol Bull 11: 99-115

Smith C, Brumsickle S (1989) The effects of patch size and substrate isolation on colonization modes and rates in an intertidal sediment. Limnol Oceanogr 34:1263-1277

Smith CR, Kukert H (1996) Macrobenthic community structure, secondary production, and rates of bioturbation and sedimentation at the Kane'ohe Bay Lagoon floor. Pac Sci 50:211-229

Snelgrove PVG, Butman CA (1994) Animal-sediment relationships revisited: cause versus effect. Oceanogr Mar Biol Annu Rev 32:111-177

Snelgrove PVR, Grassle JP, Grassle JF, Petrecca RF, Ma H (1999) In situ habitat selection by settling larvae of marine soft-sediment invertebrates. Limnol Oceanogr 44: $1341-1347$

Stocks KI (2002) Flume experiments on post-settlement movement in polychaetes. J Mar Res 60:743-762

Tamburri M, Finelli C, Wethey D, Zimmer-Faust R (1996) Chemical induction of larval settlement behavior in flow. Biol Bull (Woods Hole) 191:367-373

Thrush SF, Cummings VJ, Dayton PK, Ford R and 11 others (1997) Matching the outcome of small-scale density manipulation experiments with larger scale patterns: an example of bivalve adult/juvenile interactions. J Exp Mar Biol Ecol 216:153-169

Thrush S, Hewitt J, Norkko A, Cummings V, Funnell G (2003) Macrobenthic recovery processes following catastrophic sedimentation on estuarine sandflats. Ecol Appl 13: 1433-1455

Wheatcroft RA (2000) Oceanic flood sedimentation: a new perspective. Cont Shelf Res 20:2059-2066

Wheatcroft RA, Borgeld JC (2000) Oceanic flood deposits on the northern California shelf: large-scale distribution and small-scale physical properties. Cont Shelf Res 20: 2163-2190

Woodin SA (1998) Process-specific cues for recruitment in sedimentary environments: geochemical signals? J Mar Res 56:535-558

Woodin SA, Lindsay SM, Wethey DS (1995) Process-specific recruitment cues in marine sedimentary systems. Biol Bull (Woods Hole) 189:49-58

Zimmer RK, Butman CA (2000) Chemical signalling processes in the marine environment. Biol Bull (Woods Hole) 198: 168-187

Zimmer-Faust RK, Tamburri MN (1994) Chemical identity and ecological implications of a waterborne, larval settlement cue. Limnol Oceanogr 39:1075-1087

Submitted: December 12, 2003; Accepted: April 13, 2004

Proofs received from author(s): August 3, 2004 